\title{
PRAIA DA AMENDOEIRA: \\ COTIDIANO DE RUA EM UMA PRAIA CARIOCA
}

Pedro Zaidan ${ }^{1}$

\section{Introdução}

Não sei pedir o tom certo ao cavaquinho para cantar, não me dou bem com microfone, não gosto de palco e toco um pandeiro bem mais ou menos. Não sou sambista. Mesmo assim, tiro minha onda: verso direitinho, conheço bastante música, componho algumas e, assim, acabo somando num pagode informal. Tirar essa onda interfere na forma como experimento o mundo. Interfere também na forma como estudo o mundo que me cerca. O samba me ajuda a pesquisar e a antropologia me ajuda a compor samba.

A antropologia me ajuda a compor. E digo isto com muito carinho. Por causa dela, a palavra compor não me significa tirar alguma coisa da minha cabeça. Compor é organizar referências, códigos e elementos coletivos. É também uma tentativa de direcionar nossa interferência no mundo. Publicar uma composição é contribuir na composição de alguma realidade. E isto aproxima uma música - crônica, poema, filme, desenho, foto, sei lá - de uma etnografia. Este trabalho não deixa de ser uma composição. O fazer musical - tanto o ato de cantar, como o de compor - direcionou meu campo de pesquisa, pois foi a forma mais substancial entre as quais me fiz presente naquelas relações. Foi possível descrever uma perspectiva que colocasse o movimento em evidência.

Um dos aspectos mais relevantes do samba, para estas reflexões, é a forma como se orquestra uma roda. Para o som ficar minimamente alinhado, cada integrante deve se adequar aos seus parceiros. É um processo coletivo, no qual todos ganham importância, inclusive quem acompanha fazendo coro, batendo palmas ou mesmo observando. Tais relações de dependência mútua, no intuito da diversão, acabam extrapolando a própria diversão, abrindo espaço para outros aspectos relacionais. É um processo de pessoalização. A impressão é de que com o firmamento de uma roda com música, laços

1 Universidade Estadual do Rio de Janeiro, Brasil. Email: pedro zaidan@ hotmail.com ORCID id: https://orcid.org/0000-0001-7683-3058 
se formam. Nem todos no campo gostam de samba, mas quando participam de uma roda, geralmente se dirigem a mim com mais intimidade do que quando conversamos apenas.

Certo dia de inverno, o tempo estava fechado, com aquele vento cortando de frio. Pouquíssimas pessoas transitavam na rua. Já era noite e eu com o pandeiro, chegando aonde Duque dormia. Havia uma fogueira, protegida por uns compensados de madeira, embaixo da árvore mais afastada da calçada. Aqueci-me no fogo e aguei a comida que estava na grelha: linguiça defumada. Duque me entregou uma garrafa pet cheia de cachaça mineira e com um sorriso no rosto disse:

\section{- Peida ${ }^{2}$ não!}

Devolvi o sorriso e dei a primeira talagada. O frio melhorou e a linguiça estava boa. Peguei o pandeiro e comecei a batucar sem pretensão. Logo em seguida, apareceu um rapaz que estava devendo dinheiro a Duque. O rapaz era bom de conversa falava muito, foi chegando devagar, pegou um balde para sentar, me cumprimentou, cantou uma música e aí sim pediu um golinho da cachaça. Gargalhamos e Duque falou:

\section{- Tava demorando!}

O rapaz sorrindo responde.

- Coé, Duque, na humildade, né? Tá frio pra caralho!

Ele continuou contando história, cantando e ficando bêbado depressa. A madrugada foi passando, a comida acabou, mas ainda tinha cachaça. Naquele momento, os três estavam em situações muito semelhantes, no frio, nos aquecendo com música, papo furado, fogo e cachaça. Um assumia alguma importância para o outro. Mesmo que momentaneamente, um desconhecido - para mim, já para Duque era um conhecido com pouca intimidade - se tronou próximo. Foi possível se afetar por histórias atravessadas por realidades diferentes. Choramos juntos.

Com o nascer do sol e o fim da cachaça, nos despedimos e o rapaz falou:

2 “Amarelar", "arregar” desistir etc. 
- Vocês são foda. Quando passei por aqui, eu estava indo me drogar. Me amarro num tequinho, tá ligado, irmão? É muito bom também! Mas aí vocês surgiram com esse pandeiro e essa cachaça. Agora vou voltar pra casa tranquilão!

O rapaz foi embora para sua casa - embaixo de um viaduto próximo - e só fui descobrir seu nome por volta de seis meses depois: Reinaldo, para além de categorias das quais, no caso, se configurariam em rótulos. Morador de rua, devedor, usuário de cocaína, bebedor de cachaça... Quando o indivíduo vira pessoa, as categorias passam a incomodar, exigindo reflexões mais cuidadosas sobre as classificações que nos orientam. É a partir desses incômodos que este trabalho se desenvolve. A dificuldade está em encontrar um equilíbrio entre a descrição de um cotidiano de extermínio - no sentido da necropolítica, colocado por Achille Mbembe (2015) - e das subversões/resistências que permitem viver - num sentido rico, para além do sobreviver. Como fugir da romantização/exotização e, ao mesmo tempo, não reduzir as pessoas ao sofrimento ao qual elas estão submetidas? É assim que chegamos na Praia da Amendoeira:

A Praia da Amendoeira fica na cidade do Rio de Janeiro, é um lugar muito bonito. Sobretudo, quando a corrente marinha é de sul e a água do mar fica quente e cristalina, trazendo cardumes de tainha. De um lado da rua movimentada ficam os prédios luxuosos, do outro fica o calçadão, a praia e os quiosques. Em um pedaço da praia, amendoeiras formam uma sombra enorme, que no calor entra em perfeita sintonia com a brisa do mar. Embaixo dessas amendoeiras, podemos ver os cacarecos $^{3}$ de algumas pessoas que residem na praia.

$\mathrm{Na}$ verdade, nem todos moram na praia e os que moram, moram de diferentes formas. Alguns são nômades, outros vivem fixos, tem gente que, no verão, passa um tempo na praia para fazer um dinheiro, ou para aliviar as longas jornadas de volta para casa depois de quatorze horas trabalhando na areia sob o sol. As origens geográficas e econômicas também não são as mesmas. Tem gente de Caxias, São João de Meriti, Cidade de Deus, Taquara, Rocinha, Vidigal, Água Santa, Ilha do Governador, Morro da Congonha, Cabo Frio, Morro do Banco, Florianópolis, Morro do Borel, João Pessoa, Terreirão, Salgueiro, São Pedro da Aldeia, Argentina, Rio das Pedras, entre outros dos

3 Expressão nativa para nomear objetos em geral. 
quais não me lembro. Alguns falam em trabalho honesto, uns vendem drogas, outros simplesmente se recusam a assinar carteira. Assim como, alguns batalham diariamente pelas refeições básicas, outros possuem bens como casa própria, carro ou moto, vivendo com alguma renda. Tais condições estão longe de serem fixas. Elas estão disponíveis às vidas - muito mais às vidas do que às vontades/interesses/agências - dos atores em questão.

O escultor de castelos de areia, ex-vendedor de livros, que vive nas ruas desde os oito anos de idade será tratado aqui como Duque. Maluquete, ex-motoboy de uma lanchonete, processou seus patrões, ganhou 30 mil reais na rescisão e organizou uma barraca de bebidas em outro ponto da orla, mas quase não arma a barraca e passa boa parte do tempo na Praia da Amendoeira. Testão, garçom de uma das barracas, mora em frente à praia, pois sua esposa trabalha de zeladora em um dos prédios da orla. Tatatá possui moradia, mas passa mais da metade do ano morando como nômade na rua. Também é impossível esquecer os pescadores, ambulantes, catadores de latinha, barraqueiros, putas etc. Todos estes, quando precisam, desejam ou por qualquer outro motivo dormem na Praia da Amendoeira. Entre si, eles vivem - conversam, passam frio, festejam, discutem, brigam, dividem experiências, se aprendem etc..

A Praia da Amendoeira não corresponde a uma definição geográfica. Não se trata de algo palpável, ou mensurável, capaz de oferecer - antropologicamente características às pessoas que se submetem ou são submetidas àquele universo. Aqui, a Amendoeira é pensada como um assunto, um título ou tópico, algo que indica, mas não define, posto que seu conteúdo muda e não se repete. Ele pode estar em conexão com qualquer condicionante existente. Assuntos internacionais, fofocas locais, economia externa, política municipal, meteorologia, alguém que morre ou fica doente, o sujeito que passa andando engraçado no calçadão, tudo isso e muito mais se movimenta em meio à materialidade - plátisco, concreto, papel, álcool, fumaça, comida, carne, pele, cabelo, fezes, urina, areia, água, sal.

Participar dessas movimentações abre caminho para muitos aprendizados. A rua impõe ao indivíduo um arsenal de possíveis identificações de si. E ser identificado não depende só de uma pessoa, nem está necessariamente condicionado à sua vontade, é algo fortemente vinculado a reconhecimento, expectativas alheias e processos históricos de construção de significados. Erving Goffman (2008) e Howard Becker (2010) estão 
me inspirando aqui. Ao pensar as representações do self na vida cotidiana, Goffman fala de situações ou momentos, quando expectativas são geradas e os indivíduos vão se posicionando com mais ou menos interferência de suas ações. Howard Becker ao pensar o outsider, também entende o estar fora ou estar dentro enquanto algo contextual, uma somatória de elementos que envolve, por exemplo, a percepção de uma pessoa sobre expectativas em questão, a agência - ou, no caso desta pesquisa, a capacidade de desenrolo - e o acaso, elemento da imprevisibilidade.

O que me aproxima de ambos, portanto, é a lente que eles usam para desenvolver seus estudos. Ou seja, se trata de uma abordagem interacional sobre os comportamentos. O olhar do outro e o entendimento de si estão muito presentes na Praia da Amendoeira. Porém, daremos mais importância à imprevisibilidade e à rapidez com a qual as categorias se deslocam. Os contextos podem mudar a partir de miudezas, como: uma palavra, a chegada de alguém, uma chuva caindo etc. Por isto, não seria interessante às nossas reflexões apontar regras comportamentais ou sistematizar gestos, mas sim, perceber os movimentos, os reposicionamentos dos agentes em diferentes processos. Neste sentido, a produção de expectativas sobre o outro se encontra muito mais na dimensão da aposta, da sondagem, do que na dimensão de um possível consenso ou algo pré estabelecido. O (des)conhecimento dos próprios limites de interpretação sobre o outro é um forte elemento na Praia da Amendoeira.

Dito isto, o termo morador de rua será tratado aqui enquanto rótulo, uma dimensão relacional, algo limitado por um espaço de tempo, e suas causas não podem ser totalizadas - pois temos percepções restritas a pontos de vista. Quando o rótulo se instaura, é como se formasse um plano de fundo, as expectativas ficam mais limitadas, e os comportamentos são orientados pela gama de coisas que o rótulo pode significar.

Por exemplo, certo dia, um conhecido me pediu dinheiro (dois reais) emprestado na Praia da Amendoeira. Catei algumas moedas e coloquei em sua mão. Quando ele foi embora, outro conhecido me fala: ele é cracudo (usuário de crack)! Não precisou falar mais nada, automaticamente associei aqueles dois reais à compra de crack e senti culpa pelo empréstimo.

Só após algum tempo, consegui relativizar sobre o ocorrido. Entendo que o rótulo cracudo brotou naquele contexto e limitou, a um imaginário, minha percepção sobre um indivíduo. Nenhuma outra possibilidade, sobre como ele usaria dois reais, 
passou pela minha cabeça naquele momento. Não imaginei um cracudo comprando balas, cigarros, amendoim, água, indo ao restaurante popular, ou juntando dinheiro para comprar algo mais caro. Não: o usuário de crack pede dinheiro para comprar crack. A culpa derivou daí. Depois de pensar nisso, sinto culpa por ter sentido culpa naquele momento, pois rotulei um conhecido por causa de uma frase. Nem a garantia da veracidade da informação eu tive. E mesmo se fosse verdade, o conhecido é muito mais do que se espera de um cracudo. Qualquer pessoa é.

Superando a culpa - não faz bem a ninguém sentir isso -, é interessante pensar que o rótulo não foi estabelecido por mim, nem na relação direta com a pessoa que pediu empréstimo. Foi uma terceira pessoa que, com uma frase, modificou todo o significado da relação. No caso em questão, foi uma frase vinda de uma terceira pessoa, mas poderia ser um gesto, uma característica física, uma palavra pronunciada ou qualquer coisa que vinculasse a pessoa ao rótulo. Goffman (2004) chamaria tais elementos de estigmas.

Também é importante termos em mente a dimensão contextual do rótulo. Não foi a frase em si que me fez sentir culpa de ter emprestado dinheiro, mas também, como processei o significado coletivo dado ao rótulo cracudo. Se ouço aquela frase, se passo por situação semelhante após a reflexão que estamos fazendo aqui, meu sentimento seria - espero eu - outro. O cracudo acionaria outros sentimentos e posturas em mim, muito embora, não dissolver-se-ia toda a carga social - todo o peso e alcance para além da minha consciência - de um rótulo como esse.

A questão é a possibilidade de configurarmos infinitos tipos de relações a partir de um rótulo. Praticamente todos os interlocutores da Praia da Amendoeira precisam lidar com o racismo, com a prefeitura/guarda municipal, com as polícias civil e militar e com o rótulo morador de rua. $\mathrm{O}$ que suas vidas possuem mais em comum são as margens impostas (Das e Poole, 2008) aos seus corpos e às suas formas - diversas, mas sempre destoantes de formas elitistas - de lidar com a materialidade da praia. Essas margens produzem experiências semelhantes, pois reduzem o indivíduo à negação do existir. Tal negação, codificada - e destacada por um pesquisador (eu) - no rótulo morador de rua, dependendo do contexto, pode acionar medo, nojo, ódio, pena, carinho, admiração etc.. Ela não define, pois pauta, as direções que a interação seguirá nos miúdos. 
Ficamos combinados, então, que o termo morador de rua será pensado aqui enquanto uma dimensão relacional, um rótulo, que se instaura por um conjunto de elementos controláveis e incontroláveis pelos agentes. E, mesmo após estar instaurado, existem infinitas possibilidades a partir do que envolve ser morador de rua.

$* * *$

Este artigo é fruto de uma etnografia feita entre 2009 e 2015. Ele está dividido em 4 partes:

- Quiosque do Noca: é uma forma de avaliar a relação entre a territorialidade e o racismo na Praia da Amendoeira. Como que a solidariedade entre pretos que frequentam a praia é uma forma de se proteger em um ambiente racista. Tal proteção se configura em afirmação e disputa com os códigos daquele lugar. E como que isso fortalece o pessoal da Amendoeira.

- Castelo de Duque: esta parte descreve as estratégias/apostas de permanência. Quais códigos estão em jogo nos imaginários coletivos que orientam o Estado e marcam os caminhos de quem está na rua.

- Exu: é uma proposta interpretativa, que busca dar maior importância ao inapreensível e às contradições. É uma forma de descrever o acontecer.

- Conclusão: costura o texto e reforça a ideia de que existe uma dinâmica ampla convergindo para que o pessoal da Amendoeira não viva, mas sobreviva se adequando aos lugares aceitáveis de submissão e invisibilidade. É um exercício de pensar em que termos, em quais dimensões coletivas a necropolítica repousa na Praia da Amendoeira. 


\section{Quiosque do Noca}

Embora a Praia da Amendoeira seja um universo múltiplo, está longe de ser democrática. Dentro de um espaço demarcado, estamos lidando com uma infinidade de referências culturais, históricas, sentimentos, intenções, interesses, expectativas etc. Isso tudo movimenta aquelas relações e posiciona as pessoas na praia, em diferentes lugares ao longo do dia. A cor da pele é um elemento importante em meio a esse movimento.

O quiosque do Noca atrai muitas pessoas de outros lugares da cidade. É comum encontrar, no estabelecimento, sambistas e pessoas envolvidas na causa negra ${ }^{4}$. Noca sempre foi muito festeiro, sempre reuniu música, comida e bebida. Muitos frequentadores do quiosque, chamam essas festas de resistência. E são mesmo. Aquele local é um ponto de resistência na Praia da Amendoeira. Estamos falando de um lugar, onde a elite está sempre se reinventando - ou seja, definindo meios de diferenciação - e continua enxergando na pele branca uma das referências do que é ser elitizado. Os frequentadores do quiosque do Noca criam representações na intenção de contrariar este modelo racista.

Certo dia, Noca estava meio indignado com a posição da prefeitura em relação a uma festa que foi organizada em seu quiosque. Eles criaram dificuldades por não haver banheiro químico, nem hora para terminar. Segundo Noca, um quiosque famoso da região faz festas muito maiores e não precisa cumprir tais exigências. Ele dizia:

- Esse pessoal aqui da frente tem medo de pobre! Rico tem medo de pobre, e branco tem medo de preto, rapaz!

Ou como dizia um baluarte de uma famosa escola de samba, enquanto bebia sua cerveja:

4 Causa negra: luta contra o racismo protagonizada por pessoas negras. 
- Aqui sempre foi meio black e white, tá ligado, compadre? Eles ficam do lado de lá e a gente do lado de cá.

Discursos como esses, ajudam a pensar a relação do pessoal da Amendoeira, que passa pelo rótulo morador de rua, com os frequentadores do quiosque. Sempre presenciei relações de respeito e afinidade por ambas as partes. O elemento racismo faz essas pessoas se sentirem menos desconfortáveis quando, na Praia da Amendoeira, estão próximas umas às outras.

Podemos pensar segregação enquanto parte de um ideal elitista, embranquecedor, naturalizado e exposto em sutilezas do nosso cotidiano. A segregação, neste caso, alcança dimensões interacionais, cotidianas e menos oficiais ou legais. A maioria do pessoal da Amendoeira e do quiosque é preta. Não vou citar exemplos de racismo materializado em ações ou palavras, pois não seria preciso para provocar a sensação que quero descrever. É algo sutil e muito difícil de ser percebido por mim, que sou branco. Arrisco dizer que é um desconforto, percebido no tom de voz, nas palavras escolhidas, no olhar, nos gestos etc. É tudo feito numa sutileza que não pode ser acusada de racismo, mas causa desconforto, receio, insegurança e medo. O pesquisador Tomás Melo descreve de forma mais sensível, em seu perfil do facebook, elementos que causaram insegurança nele, após visitar sua orientadora em Icaraí:

Odeio Icaraí.

Ontem fui na casa da minha orientadora. Ela não tinha chegado, então tive que esperar. O porteiro do prédio não me conhecia e ficou com um comportamento um tanto estranho quando disse que ia esperar ali fora do prédio. Geralmente, nesses casos, eu tento entrar em algum estabelecimento e consumir alguma coisa para não ficar de bobeira na rua. Resolvi que não e fiquei parado na frente do prédio.

As pessoas passavam, ressabiadas, me olhavam e guardavam seus celulares. Eu tirei o capuz do moletom antes de descer do onibus? Check! Estava com as mãos a vista, fora dos bolsos? Check! Um grupo de 5 meninos brancos vieram em minha direção, carregando seus instrumentos. Foram se aproximando, diminuindo a voz até se calarem completamente perto de mim e passarem. Passam mais alguns transeuntes me olhando de cima a baixo. Caralho, vou ficar mexendo no celular para mostrar para essas pessoas que eu também tenho um. Uma senhora vem na 
minha direção, cautelosa, entra no prédio. Essa mulher vai chamar a polícia e pedir para me verificarem, tenho certeza, é só aguardar. Um carro da polícia passa do outro lado da rua, nada... Porra, menos mal, não quero que ela chegue aqui comigo tomando um baculejo na frente da casa dela. Ih, tão vindo de novo. Bem, agora fodeu, não vai ter jeito. Dessa vez eles tão vindo do meu lado da rua, com o carro devagar. Olham para mim, mas não pararam, beleza. Uffa, ela chegou! O porteiro se levanta novamente, vai até o carro dela, olha pra mim e volta pra dentro. Espera mais um pouco até ela acabar completamente de estacionar e ai abre o portão.

De volta pro Fonx, cervejinha na rua, conversando sobre rap com os parceiros e os verme passando devagar com os bicos de fuzil pra fora da janela, o tiozinho preto tentando pegar um taxi para ir trampar, sem sucesso. Tudo bem, tudo normal.

Moral da história? Eu devo ter mania de perseguição, certo? Certo. (Melo, 2015)

Acredito que situações e sensações parecidas sejam elementos que fortalecem muito as relações entre pessoal do quiosque e pessoal da Amendoeira. Não sei se todos os frequentadores negros do quiosque operam um discurso político a respeito da causa negra, alguns ostentam um discurso elitista, conheci também policiais em dia de folga defendendo o extermínio em favelas entre um gole e outro. Pessoas chamando pobre de vagabundo e apoiando a internação compulsória para usuários de crack. Não sei se essas pessoas bebem cerveja com cracudos em seus bairros de moradia, ou fazem churrasco com mendigos, mas na Praia da Amendoeira elas fizeram. Aposto que aquela sensação de desconforto seja um dos principais elementos de solidariedade entre o pessoal da Amendoeira e o pessoal do quiosque.

Estar próximo a isso substanciou a leitura do texto de Lélia Gonzalez, $O$ Movimento Negro na última década, no livro Lugar de Negro (Hasenbalg, 1982). Gonzalez aborda o combate ao racismo por meio de organização, articulação, direcionamentos e discursos no recorte de uma década. Nesse exercício, ela deixa evidente que tais mobilizações são diversas e se encontram em luta contra um processo racista histórico:

Na verdade, falar do Movimento Negro implica no tratamento de um tema cuja complexidade, dada a multiplicidade de suas variantes, não permite uma visão unitária. Afinal, nós negros, não constituímos um bloco monolítico, 
de características rígidas e imutáveis. Os diferentes valores culturais trazidos pelos povos africanos que para cá vieram (iorubás ou nagôs, daomeanos, malês ou mulçumanos, angolanos, congoleses, ganeses, moçambicanos, etc.), apesar da redução à "igualdade”, imposta pela escravidão, já nos levam a pensar em diversidade. Além disso, os quilombos, enquanto formações sociais alternativas, o movimento revolucionário dos malês, as irmandades (tipo N.S. do Rosário e S. Benedito dos Homens Pretos), as sociedades de ajuda (como a Sociedade dos Desvalidos de Salvador), o candomblé, a participação em movimentos populares etc., constituíram-se em diferentes tipos de resposta dados ao regime escravista. Por outro lado, que se pense nos "ciclos" da economia e seus deslocamentos (não só da população escrava, mas dos centros de decisão política), assim como nas diferenças regionais que daí resultaram. Que se pense no advento da sociedade burguesa e das relações capitalistas, com seus abolicionismos e republicanismos. E que não se deixe de pensar, sobretudo, no caráter autoritário e racista da sociedade brasileira em geral, assim como os diferentes meios que ela tem utilizado para concretizá-lo. Agora, se a gente junta tudo isso (e muito mais), uma pergunta se coloca: será que dá pra falar do Movimento Negro?

É claro que, se a gente adota a perspectiva acima delineada, não dá. Como não daria pra falar do Movimento de Mulheres, por exemplo. No entanto, a gente fala. Exatamente poque está apontando para aquilo que os diferencia de todos os outros movimentos; ou seja, a sua especificidade. Só que nesse movimento, cuja especificidade é o significado negro, existem divergências, mais ou menos fundas, quanto ao modo de articulação dessa especificidade. Deve o negro assimilar e reproduzir tudo o que é eurobranco? Ou só transar o que é afronegro? Ou somar os dois? Ou ter uma visão crítica de ambos? Deve o negro lutar pra vencer na vida através do seu esforço pessoal para, desse modo, provar que é tão capaz quanto o branco? Ou lutar com e pelo conjunto da população negra? Juntamente com não negros também oprimidos? Ou não? Por um espaço nesta sociedade? Ou pela transformação da mesma? Etc, etc. e tal... Os diferentes tipos de resposta a essas questões, e a muitas outras, acabam por remeter a gente a falar de movimentos negros no Movimento Negro. Pois é. (Gonzalez, 1982: 18-19)

Pois é, se ao falar de pessoas que se organizam em função de um propósito, a autora precisa tomar o cuidado de afirmar a heterogeneidade do movimento, imagine ao falarmos de um quiosque na praia, onde as pessoas estão presentes por propósitos variados. No entanto, a solidariedade existe e é um firmamento importante para a 
ocupação - por diferentes motivos - daqueles corpos naquele lugar. Ou seja, o fato de haver a necessidade de reforçar laços entre pessoas tão diferentes, das quais a principal característica em comum é não ser branco, já nos aponta o teor racializante e descriminatório da Praia da Amendoeira.

\section{Castelo de Duque}

Olhando para o mar, do lado esquerdo do quiosque de Noca se localiza um enorme castelo de areia. Perto dele ficam os cacarecos de Duque. Ele vive na praia da Amendoeira, onde construiu sua moradia em uma estrutura camuflada embaixo do castelo, que é imperceptível para quem passa pelo calçadão. A escultura fica na beira do calçadão e compõe um lindo cenário, com um trono de madeira e acessórios para fantasiar-se de rei ou rainha, para tirar fotos. Ao lado tem uma caixa para depositar a gorjeta após a foto. Por dentro do castelo existe uma estrutura de madeira entre 2 e 3 metros quadrados, na qual ele pendura suas roupas e guarda seus pertences (livros, lanterna, tênis, cachaça boa, etc.). O chão de areia é forrado com papelão e em cima ele coloca seu cobertor. Sua dispensa é um isopor enterrado atrás do castelo (entre a escultura e o mar) e do lado de fora, para não atrair bicho. Seu fogão é um armário de 1 metro de altura com um fogão a álcool dentro. Quando ele cozinha, ninguém vê que ele está cozinhando, pois as portas do armário ficam fechadas, parecendo um guardador de material para o castelo.

No primeiro mandato de Eduardo Paes (2009 - 2012) a política de remoções foi reatualizada (Magalhães, 2013), e a operação choque de ordem foi colocada em prática - veremos que, no caso de Duque, choque de ordem e política de remoções significam a mesma coisa. Questões político ambientais legitimaram o deslocamento de muitas pessoas para a situação de desabrigado. Na praia, o choque de ordem imperava naquele momento: proibição de altinha ${ }^{5}$, ambulantes irregulares, cadeiras e barracas sem numeração, estruturas ilegais, como bancos e mesas fincadas nas areias, além de fogueiras e eventos sem permissão. Muitas pessoas entraram na ilegalidade.

5 Esporte popular nas praias do Rio, que consiste em uma roda de pessoas que não podem deixar uma bola de futevôlei cair no chão sem usar as mãos. 
Uma barraca do choque de ordem foi instalada em frente à moradia de Duque. Recolheram - na linguagem do poder público - todos os cacarecos do pessoal da Amendoeira. As pessoas foram convidadas - também na linguagem do poder público a saírem da praia e irem para um abrigo. Maluquete descreve como se salvou:

Ai, Forno (meu apelido), vê se essa história te ajuda nessa porra que tu tá fazendo sobre "morador de rua". Choque de ordem chegou lá, pra dar um ataque, né. Ai chegou maior bondão: caminhão, polícia, delegado, aquele pessoal da ação social. Aí, meu irmão, levaram Plimplim. Levaram Plimplim à força (risos). Pegaram aqueles cacarecos daqueles maloqueiros lá no carrinho de mercado e jogaram tudo em cima do caminhão (risos). Aí, meu irmão, sentei lá naquele banquinho branco que tem do pessoal do vôlei (risos). Aí chegou o cara perto de mim:

- Você mora na rua?

- Não, não moro não.

Aí ele saiu né. E eu fui subindo e encostei perto do quiosque do Noca. Aí vem o delegado (risos):

- Olha só, hoje nós estamos só fazendo o convite.

- Coé, meu irmão, sou mendigo não.

- Olha só, dá próxima vez nós vamos levar à força e nós vamos puxar sua capivara ${ }^{6}$.

- Coé, meu irmão, você me chama de mendigo e agora me chama de bandido? Então vamos logo agora, pô. Não devo porra nenhuma pra ninguém não.

Ai ele ficou me olhando e eu falei assim pra ele:

- Aí, quer ir lá na minha casa?

- Não! Casa eu já tenho a minha!

Ai ele saiu pra lá. Só sei que ainda levaram aquele outro maluco à força. Aquele que fala assim: "é demais!". Pegaram também o Léo Negão, a mulher dele e o cachorro. Botaram o cachorro no caminhão, aí eles ficaram putos e resistiram (risos). Acabou que não levaram o casal nem o cachorro, só os cacarecos.

6 Ficha criminal. 
O castelo de areia também estava sob ameaça de remoção. Mesmo afirmando que ali era local para guardar material de trabalho, a guarda municipal disse que aquela estrutura não era para ficar ali e, por isso, seria removida em 15 dias. Houve muita apreensão sobre a situação de Duque. Ele mesmo ficou bastante confuso:

- Não sei se tento desenrolar, se boto pra foder... tá sinistro.

Respondi:

- Você precisa avaliar o que é importante. Bater de frente talvez não resolva nada.

- Eu sei, mas nada disso (as coisas que ele tem: a estrutura embaixo do castelo, vestimenta, livros, isopor, bebida, talher, etc.) me prende. Podem levar a porra toda. A única coisa é que gosto daqui entendeu?

- Entendi. Então faz o que você acha que deve fazer!

- Vou dar um trato nesse castelo! Ele tá caidinho faz tempo, aí chama atenção preguiça é um problema. Aí vamos ver no que dá.

Tal dedicação ao castelo foi sua principal forma de negociação para conseguir sua permanência. Naqueles dias, Duque me mostrou que sua obra de arte era um instrumento muito precioso. Ele, restaurou o castelo, colocou folhas de coqueiro enterrou um isopor comprido e cheio d'agua no chão, nomeando de fonte dos desejos. Também comprou uma coroa e um manto na Rua Uruguaiana e disponibilizou a quem quisesse tirar fotos. Seu castelo virou um ponto turístico na orla. Duque, vinculado àquela obra de arte, afirmou uma posição que se afasta dos rótulos de mendigo ou morador de rua. O castelo the oferece a condição de artista, algo desejável ou concebivel de estar naquela orla, diferente da população de rua.

Duque imaginava o que era necessário transparecer, em termos de apresentação de si, e agiu em função disso. Ele avaliou que o problema não era ele ou o castelo estarem na Praia da Amendoeira, embora as ações do Estado e as palavras dos seus agentes afirmavam isso. Duque percebe a importância dos significados em jogo nas interações. No caso, o aspecto abandonado do castelo configurava um problema. Ao remodelar e torná-lo uma atração turística muda-se de status, tornando possível - pela 
perspectiva do poder público, por um discurso oficial que interfere em qualquer canto da cidade - pertencer ao cenário de praia. Os interlocutores de Duque, no caso em questão, significavam sua condição e de sua obra de arte a partir dessas perspectivas. $O$ castelo serviu - e serve - não apenas como moradia, mas como instrumento de negociação com uma ordem que tem legitimidade de definir o que será nossa cidade (Lefebvre, 2001).

Após inventar seu ingresso para o imaginário oficial sobre a cidade e a Praia da Amendoeira, Duque legitimou sua estadia. Os guardas que antes ameaçavam a retirada da estrutura de areia, passaram a oferecer as quentinhas que sobravam e até se disponibilizam para a ajudar na resolução de problemas eventuais, como quando roubam alguma coisa. Segundo Duque: tá tudo dominado.

\section{Exu}

Ser morador de rua diz respeito a representações construídas historicamente, moldadas por valores culturais, econômicos, moralidades e outros diversos aspectos da nossa sociedade. No cotidiano, tais representações se materializam de múltiplas formas. Elas podem até possuir certo grau de antagonismo, invocando imagens opostas, como a do morador de rua sábio ou a do ignorante, por exemplo. Porém, elas sempre possuirão um ponto de interseção: o inaceitável. De Lucca descreve:

Até então inumerável, invisível e inominável, nos últimos trinta anos a experiência das ruas ganha número, visibilidade e nome próprio - população de rua - e assim entra na cena do espaço público paulistano e também em outras cidades do Brasil. Particularmente no centro de São Paulo a população de rua parece que está em todo lugar. É alvo de discursos e olhares, regimes enunciativos e de visibilidade. São implantados insistentes dispositivos para se ouvir, ver, registrar e falar da população de rua. Discursividades múltiplas são incitadas: declarações públicas, artigos de jornais, periódicos científicos, monografias, pesquisas estatísticas, livros - depoimentos. Visibilidades também são suscitadas: câmeras, filmes, fotos , sistemas de informação, mapeamentos estatísticos, cartazes, manifestações no espaço público. Sem falar nos agentes, instituições e outras instâncias mais 
especializadas: ONGs, albergues, uma lei municipal própria, blogs de discussão, datas e periódicos específicos, Pastoral do Povo da Rua, fóruns e mais fóruns, e, agora, um comitê interministerial próprio e um movimento social de escala nacional.

Vemos deste modo, como hoje a experiência de rua é interrogada e colonizada por um imenso campo discursivo e prático. Toda esta heterogênea rede de atores, instituições e saberes parecem carregar consigo a premissa de que é inconcebivel que alguém esteja habitando as ruas da cidade. E tal premissa é justificada de várias formas: a rua não é um lugar legítimo e digno de vida, é insalubre e prolifera doença, é espaço de abandono, anonimato e violência, além de atrapalhar a circulação e gerar insegurança entre os transeuntes, morar na rua também é uma prática juridicamente inaceitável já que por lei todos temos direito à moradia. Estas diferentes justificativas podem ser encontradas em leis, projetos urbanísticos, periódicos, protestos e outros discursos públicos, contudo, elas insistem e se tangenciam em pelo menos num ponto em comum: a experiência de vida nas ruas é algo inaceitável. (De Lucca, 2007: 19-20)

Ter consciência de tal inaceitabilidade é fundamental para nós. E quando abordamos em escala interacional, o inaceitável ganha um aspecto determinante no processo de identificação do morador de rua. Ao entender o morador de rua enquanto rótulo - que surge e ressurge em meio ao viver de alguém ${ }^{7}$ - o inaceitável vira elemento do reconhecimento, para além de reação à condição de rua. Ou seja, a condição de morador de rua é instaurada/percebida quando o inaceitável fica evidente.

Se elencarmos referências mais imediatas, se fecharmos os olhos e imaginarmos um morador de rua, provavelmente a imagem de um mendigo habitará nossas mentes. Enxergaremos alguém deitado onde se deveria caminhar, se alimentando daquilo que se deveria dispensar, defecando onde se deveria descansar, vestindo o que se deveria descartar, morando onde não se deveria morar. Entendemos facilmente o inaceitável quando ele se monta em contraste aos nossos sentidos e padrões. Porém, essas fronteiras do (in)aceitável não são estáticas, nem sempre estão colocadas. Nem sempre - muitas vezes - o morador de rua se instaura na condição de mendigo.

7 Seja experimentando o rótulo, seja rotulando, seja na condição de terceira pessoa. 
Tais fronteiras se colocam nos movimentos da vida cotidiana, configurando experiências ao indivíduo. Essas experiências, em recorrência, configuram uma condição de morador de rua. É algo que exige uma manutenção coletiva. Ou seja, a condição de morador de rua não é um lugar que se alcança, é um lugar que se reforça em meio aos contextos. É uma posição - um corpo, um indivíduo, um momento da vida - afirmada coletivamente, marcada pelo inaceitável, em constante interação com a materialidade e as imaginações.

Os processos que marcam as fronteiras do (in)aceitável são complexos e residem numa potente mistura do coletivo com o subjetivo. Existem dimensões relacionais inapreensíveis - quando prestamos atenção em alguma coisa, renunciamos outras -, altas cargas de sentimento e infinitos elementos que cabem em um contexto de curto espaço de tempo. Os processos de modulação dessas fronteiras estão profundamente ligados aos contextos e são tão singulares quanto.

Não descartar as singularidades desses processos no cotidiano pode ajudar a destacar com sensibilidade os elementos que se repetem. Ou melhor, os elementos que dobram a materialidade e os significados em harmonia com processos mais amplos. Em específico, os elementos que conduzem pessoas à inaceitabilidade, formulando caminhos, repertórios, inspirações, criatividades, violências etc., nesta direção. Compreender o que se repete e o que é inédito é um caminho para identificar em quais termos estão colocadas as resistências, subversões, disputas, negociações etc..

Por exemplo, Duque é artista quando está esculpindo seu castelo, quando se apresenta, quando é fotografado por algum turista. Porém, se ele um dia desejasse se inscrever no Programa Minha casa minha vida ${ }^{8}$, se enquadraria na população em situação de rua; se um policial desconhecido abordá-lo dormindo, fazendo comida ou suas necessidades na praia, terá o tratamento de morador de rua e toda inaceitabilidade que isso envolve. O mesmo vale para o pessoal da igreja que distribui quentinha ao longo da orla, ou quem doa roupas de frio, livros, calçados etc. Quando o rótulo se instaura, as pessoas ficam diante do universo do inaceitável.

Os meios que nos conduzem a esse universo são muitos e nem sempre são objetivos e bem definidos. Quando eu e Tatatá conversávamos sobre sua infância, por

8 Programa de habitação iniciado em 2009 pelo governo federal. 
exemplo, suas lembranças proporcionaram uma distância imensa entre nossas realidades. Enquanto minhas aventuras eram pular a roleta do ônibus, brigar por causa de futebol na pracinha ou tacar ovo pela janela do apartamento, ele descrevia a diferença entre a FUNABEM (Fundação do bem-estar do menor) e o Instituto Padre Severino (centro de reclusão para menores infratores). Segundo ele:

- A FUNABEM era maneira, fui pra lá porque dei uma pedrada na testa de um guarda municipal que me bateu de cassetete. Abriu mó bocetão! Na FUNABEM tratavam bem a gente. Dava pra aprender um monte de coisa. Eu queria até ficar lá, mas minha tia me tirou porque lá dentro eu não fazia dinheiro.

- E o Padre?

- Padre Severino? Lá a molecada já era esperta, falando de tráfico, de quem matou quem, quem vai matar quem. Lá o bagulho era mais sério.

As palavras de Tatatá levaram minha imaginação para a sua condição na rua. Vieram-me à mente algumas imagens de jornais que retratavam temas como menores abandonados, pivetes, trombadinhas, chacina da candelária etc. Inaceitável. Como essa dimensão tem força. Ela mostrou o quão diferente são as expectativas nas relações entre o mundo e nós (eu e Tatatá). A palavra morador de rua ou qualquer sinônimo não foram pronunciadas, mas ficou evidente o abismo que dividia nossas experiências de mundo e os atravessamentos que contribuíram na formação de Tatatá e na minha.

Em outro contexto, quando trabalhamos juntos numa barraca de praia, me senti mais próximo de Tatatá. Éramos garçons, dividíamos os mesmos trabalhos, tínhamos as mesmas preocupações, ouvimos desaforos semelhantes e partilhamos o merecido pôr do sol bebendo a cerveja mais cara da barraca. O valor daqueles goles no fim do dia, só foram possíveis de entender por quem vendeu o dia inteiro na praia. A sensação foi de proximidade, de entender o sentimento do outro naquele momento. Outras categorias não se dissolveram, mas não se movimentaram naquele espaço de tempo.

Não dá para desconsiderar nenhuma das duas experiências. Elas dão riqueza ao cotidiano, e à vida de qualquer personagem aqui descrito. Mais que isso, elas são constitutivas de individualidade. Interferem na imaginação, aumentam repertórios de 
possibilidades interacionais, acumulam certa bagagem - daquelas que as pessoas chamam de bagagem de vida -, ampliam o entendimento sobre o outro.

A rua oferece caminhos de empatia e identificação em meio às violências constituintes da nossa sociedade. Tais caminhos não dissolvem tais violências. Elas não deixam de existir, pois se reposicionam em meio aos movimentos das palavras, das coisas e dos corpos. Tais movimentos são irregulares - mudam cotidianamente suas formas e seus meios de alcançarem as pessoas -, são eles que marcam a singularidade de cada contexto.

A Praia da Amendoeira e as posições ocupadas nela não são dadas, estabelecidas uma vez e pronto. Além de haverem pontos de vista distintos, as posições são constantemente moldadas e cultivadas. A cada minuto é necessário um desenrolo: enxergar por outros pontos de vista, fazer negociações, se impor ou se retrair, sorrir, falar, servir ou ser servido, ajudar ou pedir ajuda etc..

A valorização desse movimento é uma das principais diferenças entre a perspectiva deste trabalho e a perspectiva de Erwin Goffman. Foi aí que a compreensão de Exu se fez importante. Exu consiste numa influência direta à forma como abordar as informações que presenciei em campo.

Exu no candomblé é um orixá, uma força da natureza. Não só representa como de fato é pensado como: início, movimento, comunicação, diversão, direção, alimentação, ganhar e perder, levar e trazer, crescimento, transformação, transferência, entre outras coisas. Para entendermos melhor, recorro à tese de Luiz Rufino, Pedagogia das encruzilhadas (2017):

Ifá, testemunho do destino e senhor da sabedoria, nos ensina que Exu precede toda e qualquer criação. Assim, Exu participa e integra tudo o que é criado, da mesma maneira que também está implicado em tudo que virá a ser destruido e tudo que ainda está por vir. É ele o princípio dinâmico que cruza todos os acontecimentos e coisas, uma vez que sem ele não há movimento. Exu é compulsório a todos os seres viventes e a todas as forças cósmicas. É ele a divindade mais próxima daqueles classificados como humanos, é o dono do nosso corpo e de suas potências, é o princípio comunicativo entre os seres, as divindades e os ancestres. Exu é a primeira matéria que 
fundamenta toda e qualquer forma de existência; é a linguagem como um todo. É o pulsar dos mundos, senhor de todas as possibilidades, uma esfera incontrolável, inapreensivel e inacabada. Ele é o acontecimento, antes mesmo da leitura deleuziana, por isso ata-se o verso que aqui nos abre caminho: "Exu nasceu antes que a própria mãe." (Rufino, 2019: 54)

A proposta de Rufino, neste caso, se encontra em uma escala epistemológica, que questiona e aponta caminhos contrários ao movimento colonial ainda em curso no Brasil. É uma proposta importantíssima, mas diferente da invocação que fazemos de Exu neste trabalho.

Aqui, o invocamos enquanto meio de dar importância ao acontecer e às dimensões incontroláveis da vida. Situar-se em meio ao caos e apostar. Isso ajuda a lidar, na pesquisa, com contradições, perdas, violências. Abre novos caminhos. Invocar Exu neste trabalho é uma forma de traduzir o aspecto incontrolável da realidade. Dar nome ao inapreensível é uma forma interessante de não esquecer os próprios limites interpretativos. E, paradoxalmente, encontrar caminhos marcados pelo não saber. Para além da prudência analítica - indispensável ao cientista social -, é um exercício de criatividade.

Levando Exu em conta, comportamentos, escolhas, perspectivas e supostas regras, ganham um cunho de aposta, de instabilidade, de sugestão. É uma boa forma de desvelar a origem das nossas expectativas, enquanto cientistas sociais, de entender nossos pontos de vista. Discriminações - e suas âncoras em processos mais amplos ficam mais evidentes.

As regras - leis, consensos, convenções, pressupostos - que normalmente são tratadas como estáticas ou mutáveis em temporalidades históricas, são percebidas aqui em seus movimentos em escala corporal. É no movimento que as regras se definem. Mais que isto, ele é necessário para a existência das mesmas. Se invocarmos Das e Poole (2008), por exemplo, veremos movimento nas noções de Estado:

Al ocuparse de este dilema filosófico en el origen del estado y el derecho como un problema etnográfico, los autores de este libro dejan en claro que este problema del origen de la ley no es un espectro fantasmagórico del pasado - 
como lo es en Agamben y su apropiación de la figura de homo sacer del derecho romano-, sino más bien el resultado de prácticas concretas en las que la vida y el trabajo están entrelazados (ver Rabinow, 2002). (Das e Poole, 2008)

A vida e a obra estão entrelaçadas. Para manter-se em determinadas posições (lugares físicos e simbólicos que o indivíduo se encontrará), para operar com elementos coletivos - constituídos em processos históricos -, é preciso de movimento, comunicação. É preciso acontecer. A agência ganha importância nesse sentido. Ela vira um elemento, um exercício de canalizar as condicionantes para a direção que se almeja. Seja para conseguir um copo d'água ou para não ser morto. Por isso, poderíamos reconhecer Exu em cada conversa, aperto de mão, sorriso, transação, contradição, roubo, negociação, festa, bebedeira, briga etc., e nas relações que produzem margem.

O fazer musical é uma movimentação. É uma das formas pelas quais atravessei aquele infinito de condicionantes em tempo e espaço, complexificando olhares em todas as direções. É a partir dele que buscaremos o equilíbrio entre o não ser e o viver:

Certo fim de tarde, estávamos cantando e batendo balde, quando puxei uma música do Mr. Catra:

\section{Vende um X9 pra mim}

(Mr. Catra)

Se faz de amigo só pra escoltar

Sujeito safado tem que apanhar

Por causa dele o meu mano morreu

O plantão do trabalho ele enfraqueceu

E causou muita morte, deixando infeliz

A família do mano que era raiz

Os moradores já querem pegar

Até grampearam o seu celular

O patrão já tá preso e mandou avisar 
Que sua sentença vai executar

(É com bala de $A K$ )

Cachorro, se quer ganhar um din-din

Vende o X9 pra mim, vende o X9 pra mim

Cachorro, me entrega esse canalha

Deixa ele bem amarrado, pega o dinheiro e rala

Sujeito safado já sabe de cor

O endereço, o contato lá do DPO

Comédia fodido que entrega o irmão

Se pego esse verme não tenho perdão

Pago quanto for mas me dá o canalha

Eu vou comer esse verme na bala

De qualquer forma não vai escapar

Eu tenho pra ele uma bolsa de AK

Cachorro!

Cachorro, se quer ganhar um din-din

Vende o X9 pra mim, vende o X9 pra mim

Cachorro!

Cachorro, me entrega esse canalha

Deixa ele bem amarrado, pega o dinheiro e rala

(UH, tá mandado, o bondão mata queimado

UH, támandado, o bondão mata queimado)

A música do Mr. Catra formou um contexto, uma atmosfera, que colocou o crime em pauta. Houve um enlace entre o assunto e os sentimentos, e os corpos, e as coisas. Enquanto eu cantava, alguns faziam barulho de tiro com a boca, o cabo da barraca virou fuzil, dedinho de arma para o alto, feições de mau, etc.. As pessoas se animaram a contar histórias, a falar de personalidades do crime, dinâmicas de poder em 
suas localidades de moradia etc..

Em meio a outras músicas e risadas, enquanto alguns falavam por experiência própria, outros contavam histórias de conhecidos, ou de lembranças de coisas que já viram. Após a cantoria, uns falavam mais, outros nem falavam ou falavam pouco. As relações com o assunto instaurado pela música redefiniram momentaneamente as posições no grupo. Ou seja, no momento em questão, algumas pessoas ganharam protagonismo, outras se apagaram e ficaram quase impercetíveis no contexto. $\mathrm{O}$ protagonista ganha os olhos e os ouvidos de seus interlocutores.

Ser ouvido e olhado mexe com vaidade. Enriquece a vida. É difícil caminhar entre o sentir-se bem e o falar o que não deve. Todo aquele repertório - contar histórias, cantar, fazer barulhos com a boca e brincar com o cabo da barraca - sobre crime pode custar a vida de quem o manifesta. O lugar onde estávamos era frequentado por todos os tipos de policial (civil, militar e federal). A presença daqueles corpos fazendo festa não é bem vista pelos moradores do bairro. Qualquer esforço para reforçar a própria imagem ao sentido de inimigo na metáfora da guerra (Leite, 2000) é um convite ao extermínio ou a alguma violência. Explicitar tal repertório pode significar tornar a própria morte legítima. Eles sabiam disso. E, mesmo assim, escolhe-se alimentar a própria vaidade, escolhe-se brincar. Duque uma vez me disse: a vida também é feita de foda-se. Tal postura, frente ao risco de morte, é um flerte com a liberdade, ou um flerte com a própria vida.

Chalhoub, ao descrever o período pós abolição nos apresenta a necessidade política de criar a noção de classes perigosas, sob uma certa missão civilizadora:

Nesse momento de incerteza em relação ao que poderia acontecer, a primeira invenção que permitiu pensar a organização das relações de trabalho em novos termos foi a teoria da suspeição generalizada - que é, de fato, a essência da expressão “classes perigosas”. Já que não era mais possível manter a produção por meio da propriedade da própria pessoa do trabalhador, a teoria da suspeição generalizada passou a fundamentar a invenção de uma estratégia de repressão contínua fora dos limites da unidade produtiva. Se não era mais viável acorrentar o produtor ao local de trabalho, ainda restava amputar-lhe a possibilidade de não estar regularmente naquele lugar. Daí o porquê, em nosso século, de a questão da manutenção da 
"ordem" ser percebida como algo pertencente à esfera do poder público e suas instituições especificas de controle - policia, carteira de identidade, carteira de trabalho etc. Nenhum desses elementos estava no cerne da política de domínio dos trabalhadores na escravidão; na verdade, até 1871, não existia sequer algum registro geral de trabalhadores. (Chalhoub, 1996: 24)

Pois bem, controle, extermínio e racismo evidenciam a relação íntima entre medo e poder, muito cara ao Rio de Janeiro. O medo é um fundamento importante do poder na sociedade fluminense. E isto não configura apenas a dimensão institucional, a constituição de um Estado. É algo que movimenta as relações em sentidos diversos, desde vestir uma farda, deixar a arma se desenhar por baixo da camisa, até uma orelha estourada de jiu-jitsu, capa e cartola, tridente, gargalhada etc..

Mergulhar numa performance atrelada ao medo - como ocorreu na Praia da Amendoeira - construído com muito esforço histórico e político, tem a ver com poder e é um risco para a vida. Ou seja, pessoas submetidas ao controle moral, material, policial, entre outros, muitas vezes lidam com o medo do outro. Tal medo, dependendo do contexto, pode promover uma sensação de liberdade e até de empoderamento da pessoa temida.

Exu, no caso, está no brotar de tal sensação, a partir do deslocamento da condição de oprimido para a condição de inimigo. O racismo não foi dissolvido, tampouco o risco de compor as estatísticas da política de extermínio em curso na cidade do Rio de Janeiro. O que esse deslocamento nos aponta, é uma contradição que desenha a liberdade do oprimido repousando no mesmo medo coletivo que o oprime. Tal contradição vira caminho ao alcançar a materialidade e os comportamentos.

A sensação de liberdade muitas vezes se conecta a algum tipo de sofrimento, quando falamos de corpos não brancos e pobres. A descrição a seguir nos aponta as dimensões, os termos nos quais a subversão de sentir-se livre pode alcançar:

Um dia, por volta das $15 \mathrm{~h}$, Tatatá estava muito bêbado dando tapas e chutes em um poste de concreto e berrando no calçadão. Um policial militar se aproximou e mandou-o parar. Tatatá não parou e recebeu um tapa no rosto. Após absorver o tapa, ele parou, olhou dentro dos olhos do policial e disse: 
- Olha só, você é um homem da lei. Precisa ser brabo! Então, quando for dar um tapa em alguém, bate igual homem.

O policial, muito irritado, só falou isso:

- Ahé?

E aplicou um tapa com toda sua força no rosto de Tatatá. Com um olho fechado e um sorriso no rosto, Tatatá responde em voz alta.

- Agora sim! Agora eu posso te chamar de policial! Bate do outro lado agora, pra ficar zero a zero!

O policial obedeceu Tatatá e deu outro tapa. Em seguida colocou as algemas e o levou para a viatura, em meio a muitos expectadores. Dentro do carro, Tatatá - segundo ele disse - não parou de falar:

- Se me matar aqui você estão fodidos! Tenho parente aqui no bairro, hein!

- Tu é chato pra caralho hein! Cala a boca, desgraça!

O policial batia com a ponta do cassetete na coxa de Tatatá, com ele dizendo: 
- Me falavam que isso doía, mas não acreditava, não to sentindo agora, mas amanhã, hein!

Chegando à delegacia, Tatatá entrou acusando os policiais de terem batido nele sem motivo. O delegado achou que o bêbado iria causar problema e então o liberou.

Duque uma vez me disse que queria ser igual ao Tatatá. E eu não entendia, pois enxergava no dono do castelo uma enorme competência para se relacionar e subverter muitos momentos de impotência. Após o ocorrido do poste, entendi melhor o que Duque quis dizer. Enquanto uma pessoa solícita ao desenrolo, ele precisa muitas vezes assumir um papel de submissão, enquanto Tatatá, como Duque diz, liga o foda-se. Fingir submissão, embora seja eficiente em muitas situações, pode ser desagradável. Significa reconhecer/reforçar alguma hierarquia, muitas vezes codificada em humilhação, muitas vezes codificada em morte:

Duque às vezes jogava vôlei com os coroas da rede lá de baixo (outro ponto da praia). Um dos coroas o tratava muito bem. Sua esposa e seus filhos o conheciam. A esposa, em especial, gostava muito de Duque. Certo dia, pela manhã, seu filho passando pelo castelo de areia ao lado de sua babá negra, falou olhando para ele:

- Olha lá, o preto filho da puta!

Revoltado, Duque respondeu:

- Vai tomar no cu, filhote de merda! Tu que é filho da puta! E você? - Se referindo à babá - Não faz nada? 
Os dois, babá e criança, seguiram o caminho assustados. Quando chegou a noite, o menino volta com seu pai, para falar com Duque. Empunhando uma pistola, o pai obriga Duque a pedir desculpas ao seu filho. O dono do castelo responde:

- Você sabe o que o seu filho fez?

- Não interessa. Como você xinga uma criança assim?

- Você não sabe o mal que você esta fazendo ao seu filho.

- Não interessa! Pede logo desculpas!

Duque me disse que o ódio o fez chorar durante a noite toda, por ter pedido aquelas desculpas. Que se durante aquelas horas tivesse acesso a uma arma, teria enchido aquele filho da puta de tiro. Disse também que teve que cruzar semanalmente com aquelas pessoas.

Esse foi o preço - reconhecível, dizível, imediatamente perceptível - das desculpas de Duque. Ninguém sabe o que realmente teria acontecido se ele se negasse a pedir desculpas. No entanto, todos sabem o que o coroa poderia fazer naquele momento. A morte estava contida nesse poder, na arma, no escuro da noite, na falta de gente na rua, no ódio do olhar, nas cores dos corpos presentes, no contexto. Contrariar isso tudo, morrendo ou não, inspira libertação. Poderíamos interpretar que Duque escolheu a vida à sensação de liberdade.

No entanto, essa é uma interpretação que só pode ser feita após o ocorrido. Descrevê-la enquanto dois caminhos - vida ou sensação de liberdade - bem definidos, evidentes, não ajuda a dimensionar contextos semelhantes. Nem sempre a morte matada conta com escolhas conscientes. Às vezes não se tem chance de escolher. Ou, até quando existe tal possibilidade, a consciência pode ser traidora. A consciência é um elemento contextual, exige alguma bagagem de vida, algum equilíbrio mental, sorte, ou seja lá o que for. Para ser sincero, traçar qualquer regra sobre isso consistirá em um ato falho. Estamos falando de apostas. Duque se viu em uma situação e humilhadamente agiu/apostou. Ele poderia ter morrido mesmo pedindo desculpas. 
Tatatá também apostou. A questão é entender o que está imbricado nessas apostas. A forma de Tatatá subverter um momento de impotência foi se tornando um problema. Não se trata de um problema momentâneo. Ele entra em diálogo simbolicamente com imaginários que remontam um indivíduo enquanto problema social. Isto implica na forma de falar, no conteúdo da fala, nas gírias certas, nos gestos certos, nos olhares etc. Ao comentar o ocorrido do poste, Duque falou:

- Ele sabia onde estava. Pode até ser doido, mas nunca faria isso em Caxias ${ }^{9}$.

Tatatá sabia que em um lugar luxuoso, os excessos da polícia possuem outros limites até para não brancos e pobres. Ainda mais, sob a luz do sol e os olhares de todos. Além disso, ele se tornou em um problema e não numa ameaça. A fronteira entre problema e ameaça é extremamente complexa e impossível - para mim - de ser definida intelectualmente. Envolve intuição, subjetividades e um monte de elementos contextuais. É preciso muito conhecimento para se posicionar/apostar nessa fronteira. Sobretudo quando a perda da própria vida está na gama de possibilidades do momento, habitando a imaginação.

A possibilidade de transformar a violência contra si em algo a seu favor, da forma como Tatatá fez, não fazia parte da minha imaginação. Mesmo abusando da autoridade, mesmo aplicando um tapa no rosto - uma das expressões máximas do subjugar - o policial não cumpriu sua função de manter a ordem, nem a intenção de oprimir ou humilhar. A violência não estava no ato, mas no significado dado a ele.

Assim como a subversão de Tatatá não ficou restrita àquele momento. Esta reflexão é um exemplo disso. Os caminhos do tapa subvertido por Tatatá alcançam o hoje, movimentando pensamentos e matéria. O fato de você estar lendo sobre isso agora é um exemplo desse alcance.

9 Duque de Caxias, município da baixada fluminense. 


\section{Conclusão}

As experiências de vida que destaquei são atravessadas por precariedade, racismo, machismo e um amontoado de violências. Tais violências interferem nas suas formas de trabalhar, descansar, dormir, tomar banho, cagar, beber, fumar, cheirar, brincar, transar, festejar. Tais violências não restringem tudo isso a formas específicas ou bem definidas - vimos como os interlocutores fazem suas coisas com autenticidade. Tais violências não lapidam, elas pautam a criatividade e as formas de viver. Existe um universo em constante movimento, inventado/vivido a partir dessas violências, no qual a morte, a dor corporal e psíquica e a perda material estão sempre em jogo, são sempre uma realidade iminente. Assim, pensar por meio do rótulo morador de rua foi uma escolha, um caminho para abordar com sensibilidade esse universo.

O imaginário que vende a cidade do Rio de Janeiro não contempla as formas como o pessoal da Amendoeira se relaciona com aquele espaço. $\mathrm{Na}$ verdade, não quer contemplar a dissociação a uma forma hegemônica, muito bem definida e identificável em novelas, propagandas e agências de turismo, por exemplo. Tal forma envolve comportamentos, o tipo de consumo, mas também os corpos em suas formas, cores e vestimentas. É na identificação dessa dissociação que as violências repousam.

Porém, é importante atentarmos a um detalhe:

Certa vez, como ouvinte, presenciei Luiz Antônio Simas afirmar que historicamente o Rio de Janeiro teve que lidar com uma contradição: os pobres não poderiam ficar tão perto para que seu cheiro não fosse sentido, nem tão longe para que eles pudessem colocar mesas de café da manhã diariamente nas casas da elite. Se por um lado, as pessoas são indesejadas quando fogem de um modelo ideal do carioca - e isto se reflete na arquitetura (Frangella, 2004) da cidade, nas leis, e no tratamento das instituições heterogêneas (De Lucca, 2007) que lidam com o tema - por outro lado, eles são desejados quando estão servindo. Quando vendem amendoim, catam latinhas, vendem drogas, armam as redes de vôlei, vendem artesanato, tomam conta do carro para não ser rebocado, carregam peso do calçadão até a areia, etc. Neste imaginário de 
cidade, tais papéis são considerados subalternos, ou, em muitos casos, invisíveis e não constituintes daquela realidade.

A subversão a uma lógica opressora - da qual o extermínio é sua representação máxima - é uma necessidade daqueles que se encontram, de alguma forma, numa condição inaceitável em meio a esse jogo de (in)aceitações. Tal necessidade corresponde aos anseios de viver para muito além da sobrevivência. É preciso subverter/resistir para viver. E viver, neste caso, envolve a complexidade e a riqueza da experiência no mundo. Tem a ver com liberdade, com sorriso, com poder de escolha. Mas também com morte:

\begin{abstract}
O que liga o terror, a morte e a liberdade é uma noção "extática" da temporalidade e da política. O futuro, aqui, pode ser autenticamente antecipado, mas não no presente. O presente em si é apenas um momento de visão - visão da liberdade que ainda não chegou. A morte no presente é mediadora da redenção. Longe de ser um encontro com um limite, fronteira ou barreira, ela é experimentada como "uma libertação do terror e da sujeição". Como observa Gilroy, essa preferência pela morte diante da servidão contínua é um comentário sobre a natureza da liberdade em si (ou sua falta). Se essa falta é a própria natureza do que significa para a existência do escravo ou o colonizado, essa mesma falta é também precisamente o modo pelo qual ele ou ela reconhece sua própria mortalidade. Referindo-se à prática de suicídio em massa ou individual por escravos encurralados pelos caçadores de escravos, Gilroy sugere que a morte, nesse caso, pode ser representada como agenciamento, já que a morte é precisamente aquilo por que e sobre o que tenho poder. Mas também é esse espaço em que a liberdade e a negação operam. (Mbembe, 2016: 146)
\end{abstract}

Mbembe está pensando a partir de formas contemporâneas que subjugam a vida ao poder da morte (necropolítica). Ele aponta a criação de mundos de morte. Seria a morte pautando as formas de existir, posicionando pessoas no status de mortos vivos:

(...) Além disso, propus a noção de necropolítica e necropoder para explicar as várias maneiras pelas quais, em nosso mundo contemporâneo, armas de fogo são implantadas no interesse da destruição máxima de pessoas e da 
criação de "mundos de morte", formas novas e únicas da existência social, nas quais vastas populações são submetidas a condições de vida que lhes conferem o status de "mortos-vivos". O ensaio também esboçou algumas das topografias reprimidas de crueldade (fazenda e colonia, em particular) $e$ sugeriu que, sob o necropoder, as fronteiras entre resistência e suicidio, sacrificio e redenção, martírio e liberdade desaparecem.(Mbembe, 2016: 147)

Mbembe cita Paul Gilroy, pois, ao analisar a relação senhorXescravo por meio da dialética hegeliana, Gilroy entende que senhor e escravo legitimam um a existência do outro: um senhor não é senhor sem escravo e o escravo não é escravo sem senhor. Ao tomar consciência disso, o escravo, ao eliminar a própria existência, ao se suicidar, enfraqueceria a existência do senhor e a própria lógica escravocrata.

Reconhecer Exu, como foi descrito aqui, permite acessarmos um mundo de morte a partir da Praia da Amendoeira. No entanto, é fundamental traçarmos algumas particularidades, as quais se dissociam das descrições de Mbembe ao pensar nas fazendas de escravos e nas colônias. Se dissociam, pois a realidade da Praia da Amendoeira não se organiza a partir do modelo escravocrata de um passado recente da nossa história. As referências descriminatórias, nesta sociedade de 130 anos pós abolição, habitam as relações de outras formas, mobilizando outros símbolos, se acomodando em outras dinâmicas de poder e morte. E, ao mesmo tempo, agindo nos mesmos corpos.

Na Praia da Amendoeira, o mundo de morte coexiste, no mesmo espaço físico, com o mundo dos soberanos/cidadãos. As fronteiras entre um mundo e outro se configuram numa dinâmica de significados. Elas podem ocorrer nas recriações da areia - como o castelo de Duque -, nas sombras das amendoeiras, nas formas de lidar com uma lixeira, com um policial, com o chão da rua. Não são fronteiras inegociáveis, justamente por existirem no movimento e entre as complexidades que configuram um indivíduo.

Neste sentido, a liberdade vem em forma de sensações. E isso é diferente de um estado de existência. Sentir-se livre tem a ver com os detalhes do cotidiano. Recriar a areia aprisiona e liberta Duque. O quiosque de Noca se impõe e nega, na aglomeração e na festa, o mundo dos mortos vivos. Liberdade, na forma como esses mundos coexistem, tem a ver com a decisão de levar um tapa, de cantar proibidão, de andar pela rua 
gingando depois de cheirar cocaína, de falar alto, de se fazer escutar, de observar um ônibus lotado enquanto bebe cachaça na calçada, de comer algo gostoso, de poder ajudar alguém, de pagar algo para alguém, de ter poder de escolha, de ter dinheiro para pegar um ônibus, de olhar no olho do playboy ${ }^{10}$ e perceber o medo dele, se desapegar das perdas, se desapegar do medo da morte.

E, neste último ponto, a noção de morte no presente se estica. Pois a morte iminente também media a liberdade. Nem sempre o indivíduo se liberta morrendo, na Praia da Amendoeira. Abraçar a morte em função da liberdade nem sempre significa morrer. Ao mesmo tempo, a liberdade é um lampejo, é contextual. Porém, isto não esvazia a necropolítica. Ela está deslocada para outros termos, para além das tecnologias e ordenamentos de morte.

Flertar com a possibilidade de se sentir livre e continuar vivendo não abona o fato de que pessoas continuam morrendo de morte matada por se encontrarem em condições inaceitáveis, ou simplesmente por serem não brancas. Desse modo, não se torna possível pensar com profundidade sobre pessoas que passam pelo rótulo morador de rua e suas relações com a materialidade, suas formas de subverter e resistir em algum espaço sem pensar na morte enquanto elemento iminente. Na verdade, não seria possível pensar com profundidade a dinâmica de uma praia em uma região nobre do Rio de Janeiro sem levar em conta a morte matada enquanto elemento.

\section{REFERÊNCIAS}

AMADO, Janaina. O grande Mentiroso: tradição, veracidade e imaginação em história oral. São Paulo: História, 1995.

BECKER, Howard. Falando da sociedade. Rio de Janeiro: Zahar, 2010.

10 Apelido dado ao jovem de classe média. 
BECKER, Howard. Outsiders: estudos de sociologia do desvio. Rio de Janeiro: Zahar, 2009.

BRESCIANI, Maria Stella. Londres e Paris no século XIX: O espetáculo da pobreza.

São Paulo: Editora Brasiliense, 2009.

CERTAU, Michel. A invenção do Cotidiano. Petrópolis: Vozes, 1998.

CONCEIÇÃO, Wellington da Silva. "Quem disse que ele era bandido?”: Biopolíticas de controle e de extermínio em um episódio da violência urbana carioca. Salvador: XVI Congresso Brasileiro de Sociologia, 2013.

DAS, Veena \& POOLE, Deborah. El estado y sus márgenes. Etnografías comparadas. Cuadernos de Antropología Social, n. 27, 2008.

DE LUCCA, Daniel. 2007. A rua em movimento: experiências urbanas e jogos sociais em torno da população de rua. Dissertação (Mestrado em Antropologia Social) Faculdade de Filosofia, Letras e Ciências Humanas, Universidade de São Paulo, São Paulo.

FAULHABER, Lucas. SMH 2016: Remoções no Rio de Janeiro olímpico. Rio de Janeiro: Mórula, 2015.

FOUCAULT, Michel. A microfísica do poder. São Paulo. Graal, 2011.

FRANGELLA, Simone. Corpos urbanos e errantes. Campinas: UNICAMP, 2004.

FRANGELLA, Simone. Moradores de rua na cidade de São Paulo: vulnerabilidade e resistência corporal ante a intervenções urbanas. São Paulo: Cadernos Metrópole, 2005 .

GILROY, Paul. O Atlântico Negro: modernidade e dupla consciência. São Paulo:

Editora 34, 2001.

GOFFMAN, Erving. A Representação do Eu na Vida Cotidiana. Petrópolis: Vozes, 2008 .

GOFFMAN, Erving. Estígmas. Petrópolis: Vozes, 2004.

HARVEY, David. A produção capitalista do espaço. São Paulo, Annablume, 2005. 
HARVEY, David. Cidades rebeldes: do direito à cidade à revolução urbana. São Paulo: Martins Fontes, 2014.

HOBSBAWM, Eric. Bandidos. São Paulo: Paz e Terra, 2002.

KATZ, Jack. Seductions of Crime: moral and sensual attractions in doing evil. Estados Unidos: BasicBooks, 1988.

LEEDS, Anthony; LEEDS, Elizabeth. A sociologia do Brasil urbano. Rio de Janeiro: Zahar, 1978.

LEFEBRVE, Henri. O direito à cidade. São Paulo: Centauro, 2011.

LEITE, Marcia Pereira. Entre o individualismo e a solidariedade: dilemas da política e da cidadania no Rio de Janeiro. Revista Brasileira de Ciências Sociais, 2000.

MAGALHÃES, Alexandre. O 'legado' dos megaeventos esportivos: a reatualização da remoção das favelas no Rio de Janeiro.In: Revistas Horizontes Antropológicos , n. 40, jul/dez 2013.

MBEMBE, Achille. Necropolítica. Rio de Janeiro: Arte \& Ensaios, 2016.

MELO, Tomás. A rua e a sociedade. Curitiba: UFPR, 2011.

MELO, Tomás. https://www.facebook.com/tomas.melo.7?fref=ts

MILLS, Wright. A imaginação sociológica. Rio de Janeiro: Zahar, 1975.

MOTTA, Marly. Entre o Castelo e o Aterro: a identidade do Rio quatrocentão. In: CARNEIRO, Sandra de Sá, SANT’ANA, Gabriel (orgs.). Cidade: olhares e trajetórias. Rio de Janeiro: Garamond, 2009.

O’DONNELL, Julia. A invenção de Copacabana: culturas e estilos de vida no Rio de Janeiro. Rio de Janeiro: Zahar, 2013.

O’DONNELL, Julia. De olho na rua: a cidade de João do Rio. Rio de Janeiro: Zahar, 2008 .

PARK, Robert Ezra. A cidade: sugestões para a investigação do Comportamento Humano no meio urbano. In: VELHO, Otávio Guilherme (org.) O fenômeno urbano. Rio de Janeiro: Zahar, 1973. 
PIEROBON, Camila. Tempos que duram, lutas que não acabam: o cotidiano de Leonor e sua ética de combate. Rio de Janeiro: UERJ, 2018.

PERLMAN, Janice. O mito da marginalidade. Rio de Janeiro: Paz e Terra, 2002.

PRANDI, Reginaldo. Exu, de mensageiro a diabo. Sincretismo católico e demonização do orixá Exu. São Paulo: Revista USP, 2009.

ROCHA, Lia. Uma favela diferente das outras? Rio de Janeiro: Quartet, 2013.

RUFINO, Luiz. Pedagogia da encruzilhadas. Rio de Janeiro: Mórula, 2019.

RUI, Taniele. Nas tramas do crack: etnografia da abjeção. São Paulo: Terceiro Nome, 2014.

SARACENI, Rubens. Diálogo com um executor. São Paulo: Mandras, 2013.

SARACENI, Rubens. O Guardião da Meia Noite. São Paulo: Mandras, 2002.

SILVA, Hélio. Situação etnográfica: andar e ver. Porto Alegre: Horizontes Antropológicos, 2009.

SILVA, Hélio. Vozes do meio fio. Rio de Janeiro: Relume Dumará, 1995.

SIMMEL, Georg. A Metrópole e a Vida Mental. In: VELHO, Otavio (org.). O fenômeno urbano. Rio de Janeiro: Guanabara, 1987.

SILVA, Luiz Antonio Machado. Quarenta anos de sociologia das classes populares urbanas. In: CARNEIRO, Sandra de Sá, SANT'ANA, Gabriel (orgs.). Cidade: olhares e trajetórias. Rio de Janeiro: Garamond Universitária, 2009.

SILVA, Maria Lais Pereira. Favelas Cariocas 1930 - 1964. Rio de Janeiro: Contraponto, 2005.

SIMAS, Luiz Antônio. Pedrinhas Miudinhas. Rio de Janeiro: Mórula, 2013.

SOARES, Luiz Eduardo. Cabeça de Porco. Rio de Janeiro: Objetiva, 2005.

VAINER, Carlos. Cidade de exceção: reflexões a partir do Rio de Janeiro. Paper apresentado no XIV ECONTRO NACIONAL DA AMPUR, 2011.

VALADARES, Lícia. A invenção da Favela. Rio de Janeiro: FGV, 2008. 
VELHO, Gilberto. Individualismo e Cultura: notas para uma antropologia da sociedade contemporânea. Rio de Janeiro: Zahar, 1981.

VELHO, Gilberto. Observando o familiar. In: NUNES, Edson de O. (org.) A aventura sociológica. Rio de Janeiro: Zahar, 1987.

WHYTE, William Foote. Sociedade de Esquina. Rio de Janeiro: Zahar, 2005.

ZALUAR, Alba. A máquina e a revolta. Rio de Janeiro: Brasiliense, 1985.

Recebido: $28 / 05 / 2020$

Aprovado: 04/09/2020 